\title{
From the Beginning till the End: an interview with Josephine Ann Endicott
}

\author{
Josephine Ann Endicott \\ Tanztheater Wuppertal Pina Bausch - Wuppertal, Germany
}

Marcelo de Andrade Pereira

Universidade Federal de Santa Maria - UFSM, Santa Maria/RS, Brazil

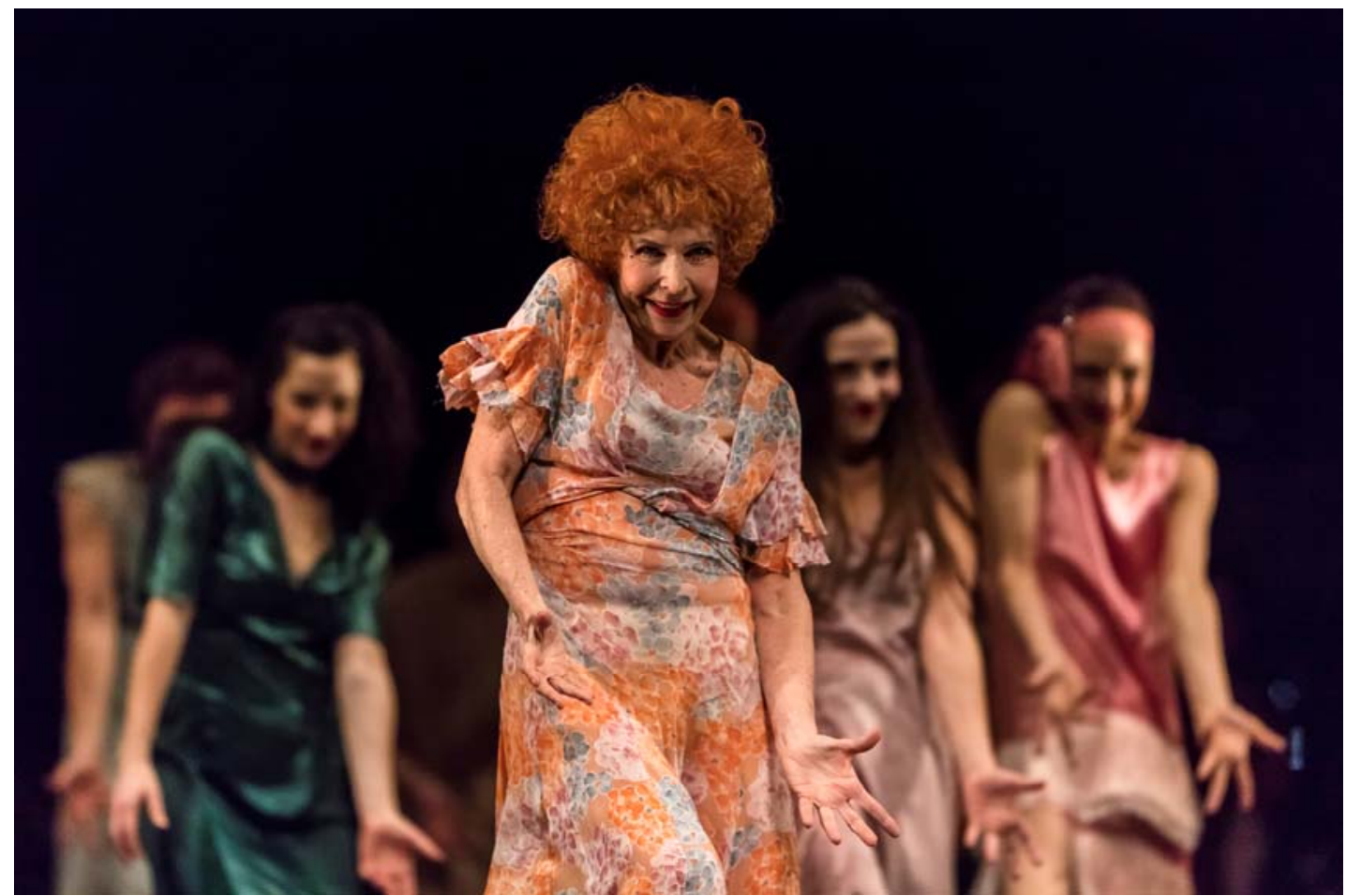

Image 1 - Josephine Ann Endicott, in Die Sieben Todsünden, Tanztheater Wuppertal Pina Bausch,

Wuppertal, 2018. Source: Photo by Meyer Originals (copyright).

In January 2018, almost one decade after its last staging, the Wuppertal ensemble re-staged, in its headquarters, Bertolt Brecht and Kurt Weill's iconic play Die Sieben Todsünden, choreographed in 1976 by Pina Bausch. In the show program there was also a second part entitled Fürchtet euch nicht, composed of other songs from the historic duo. On the many occasions when this spectacle was staged and re-staged between 1976 and 2018, one presence was constant, inside and outside of the stage: the Australian dancer and rehearsal director Josephine Ann Endicott. A constant member or guest colleague of the Tanztheater since its 
establishment, Jo, as she is called, kept a very close and long-term friendship and partnership with Pina Bausch, having occupied central positions in some classical staging, especially in the abovementioned Die Sieben Todsünden, as well as in Komm tanz mit mir, from 1977 and Kontakthof, from 1978. Until nowadays she is one of the major disseminators of Bausch's legacy.

The first meeting with Jo happened in Café Moritz, close to Lichtburg in Wuppertal Barmen where the company rehearsals are developed. During this brief tête-à-tête, we spoke informally about Pina, the staging in course, the new directions of the company, among other issues. It would be pointless to describe in words the strength of her presence. In order to provide more precise and deeper information, Jo preferred to answer my questions in writing, as she was afraid that she could not stay for long at that moment because of the Todsünden staging. In this sense, what follows refers to this e-mail exchange which happened between January and April of 2018, a period during which, Jo previously having spent almost 2 months in Paris France rehearsing the Paris Opera dancers for the re-staging of Pina's Sacre and directly following the Todsünden her commitment as rehearsal director for Orpheus und Eurydike with the Paris Opera in which, on that occasion, also had the presence of Dominique Mercy. Jo is very busy. And tired. After Orpheus several meetings are planned plus an interesting newly born idea of the possibility of performing The Rite of Spring with an African cast of African dancers in Africa.

Thus, I thank to Jo for the rich, warm and continuous dialogue that has been established since our initial meeting in Wuppertal. This interview is only an initial part of a very fruitful conversation; here, it is almost an appetizer! In the following months, the Brazilian audience will hear more about Jo and Pina. However, this is a matter for another meeting. Once again, I thank Eddie Martinez, a friend and work partner, for his huge kindness when providing what follows. 
Marcelo de Andrade Pereira - Why did you choose to be a dancer?

Josephine Ann Endicott - I never chose or wanted to be a dancer. It seems it choose me. I just loved to dance and I was born with this amazing gift. As a child I cried a lot. My two brothers were continually pestering me. My mother and father quarrelled often. At the age of 7 my mother took me to a ballet school in one of the suburbs close to home. The movements both physically, rhythmically and mentally came easily to me. Taking class made me happy. I know it sounds like a fairy tale but truly it was like this - I stopped crying!

Marcelo de Andrade Pereira - For how long did you study dance before meeting Pina and entered the company? How was your training? Did you dance with any other company before?

Josephine Ann Endicott - At the age of 15 years my teachers sent me off to an audition for the most known School in Australia. The Australian Ballet School. I was chosen as one of the best 8 girls throughout the entire country. The School was based in Melbourne. I was very sad to have to leave my home in Sydney, my mother, father, brothers and friends. It took me ages to adjust. I knew no-one in Melbourne and felt very lonely.

My training was basically classical - R.A.D. but it included lessons in Modern, Music, Mime, Jazz, Character, Choreology and Pas-des-Deux. I loved to be in $\mathrm{Tu}-\mathrm{Tu}$, pink tights and pink satin pointe shoes. After a period of 2 years at School the best two to three girls and boys were then selected to enter The Australian Ballet Company. I happened to be one of them but after 4 years I left the Australian Ballet Company and flew to London. I was tired of being told what a wonderful, highly talented dancer I was but that my face was too round and if I couldn't have some teeth extracted so my face would look smaller and perhaps loose 2 or 3 kilos. Anyway! The life of a dancer is/was never easy for the majority of us I would say.

Marcelo de Andrade Pereira - Could you tell us a little about starting to work with Pina? How did you meet her? Where? When?

Josephine Ann Endicott - I first met Pina Bausch in 1973 at the Dance Center London I was 23 years old. Pina 34 years. Pina had just been appointed Director of the Wuppertal Ballet and was searching for dancers. 
I was participating in a classical ballet class in which Pina Bausch just happened to be observing. I had no idea who she was - back then only insiders were acquainted with her work. After class, she spoke with me, asked if I was looking for a job - which I wasn't BUT... because of the unusual, authentic, simple almost humble way she expressed herself or her choice of words or Aura or her fascinatingly beautiful face, those blue eyes, her long fine expressive hands, those big wide steps she took when walking or the way she looked so deeply at me - who knows - but for some reason I answered "yes". It was a real true case of love at first sight, as simply as that. Yes! I fell in love with Pina in 1973. And she fell in love with me. Meeting Pina was perfect. From the moment our eyes meet it felt like I was under her spell. She loved me for who and what I was - with and without kilos.

Marcelo de Andrade Pereira - How did you approach each other and work together?

Josephine Ann Endicott - As time and years passed by we seemed to be continually discovering, examining and learning from each other finding new paths to where the work was leading. Pina was my leader and I just kept on and on following her on her mission as long as I could - helping and supporting her on her way, both as a dancer and as assistant - and of course believing in her and our work.

Marcelo de Andrade Pereira - How did you get to Wuppertal?

Josephine Ann Endicott - In 1973 I flew from London to Dusseldorf and then took train onwards to end up in not so beautiful German cold, grey and rainy city of Wuppertal - once again not knowing a soul nor speaking a word of the German language nor having a place to stay and little left of my savings in my pocket but I was curious to finally begin this new way of working with Pina.

Marcelo de Andrade Pereira - How was the work in the early days? Could you tell us about the creative process then? Have it changed during the time?

Josephine Ann Endicott - Based on human feelings Pina freed, renewed, emancipated and revolutionized the soul of dance aesthetic allowing it to blossom and spread into many different directions at the same time allowing her dancers to remain creative individuals under her wings. Indeed 
over the many, and decades the work has changed in their themes - perhaps the later pieces were lighter, more entertaining. Later, around 1986 Pina began to work on a co-production basis with other countries. This proved as a great influential source of inspiration to Pina and her dancers shaping her works with other colors, flavors, moods and freshness. Pina's last creation was a co-production with Chile in 2009.

Marcelo de Andrade Pereira - Could you tell us if there were any particular phases and if so, how they were? Were there any remarkable moments during those years that you would like to share?

Josephine Ann Endicott - Through the creations and years of work we did together I was able to find, develop and allow myself to be myself. Dance has guided me thru life.

I am now 68 years old and passing on with love, respect, grace and care as much of my knowledge to the younger generation of dancers as rehearsal director as perfectly as I possibly can - the older pieces like Kontakthof, Arien, Sacre, Orpheus, Brecht/Weill evening "The seven deadly sins"- the works I know best.

Marcelo de Andrade Pereira - What kept you in the company for so many years? What's the secret?

My love and loyality to and for Pina. She had somehow the power over me - I remained fascinated under her calm, persuasive, assuring, direct, honest, sincere, courageous, strong and powerful, unique, witty, gifted, highly sensitive, possessive, understanding, generous, extremely disciplined, fanatical, driven to create, genius and her vision has kept me believing in her works and creations. It is absolutely necessary that the world continues to see those devastatingly, beautiful genius works of Pina. I will keep teaching as long I can still feel her presence inside me and as long as I believe I can.

Marcelo de Andrade Pereira - You probably have changed as artist during all this time. What are the moments that changed you in this process?

Josephine Ann Endicott - As an artist and with life experience one is always growing. Age has slowed me down a little but till now not so much. I have been very lucky with my body - no real serious injuries. When she 
passed away I felt lost and incomplete without her. I don't like to speak about this period of my life but I broke down.

Marcelo de Andrade Pereira - If you could give any advice for young dancers in a creative process in dancing, based on your experience, what would it be?

Josephine Ann Endicott - Let's hope you will be as lucky as I was and find your own Pina in some way or another.

Marcelo de Andrade Pereira - What were the challenges of re-staging a piece with non-professional dancers like the Kontakthof with teenagers?

Josephine Ann Endicott - Kontakthof is a timeless piece. Of course it can be performed by non-professional teenagers but...... I was a little afraid of the challenge with teenagers as from my own experience in having brought up three children I know more than well just how difficult the age of Puberty can be. It was hard. One had to treat them carefully, individually, patiently somehow discreetly building up their trust from week to week month to month. It was a wonderful adventure with them. I was so proud of the end results and their fantastic, young, energetic, innocent Kontakthof Marcelo de Andrade Pereira - You've helped to build the history of dance theatre. In your opinion what's the most important legacy of Pina and the company in the future of dance?

Josephine Ann Endicott - To try to keep the spirit and humanity in as many of her works alive as possible and to support the documentary works of the Pina Bausch Foundation set up and headed in her memory by Pina's son Salomon Bausch.

Marcelo de Andrade Pereira - Do you think that the Dance Theater (that particular type of dance and theater in which Pina was the great figure) will persist in the future?

Josephine Ann Endicott - I would like to think and hope so but Pina was such an artist, inventor and instigator of human emotions. She was magical.

Marcelo de Andrade Pereira - Do you think dance theater in the contemporary world has the same power it had in the 1970s, 80s and 90s?

Josephine Ann Endicott - Yes I do. 
Marcelo de Andrade Pereira - Today we see very young dancers becoming part of the company, how does it modify your work or the work of Pina?

Josephine Ann Endicott - I try to get very close to the soul and character of the person I am working with and to be honest, understanding and direct. I try to guide the dancer as best as I can along the whole difficult way until I feel she has it and the role now belongs to her and is not any longer mine. I like to see and watch them grow from rehearsal to rehearsalfrom performance to performance.

Young dancers need time to understand and grow into the work of Pina. Unfortunately they will not get to know her personally. The older works are in their making so strong that they hopefully can live and be performed under careful loving eyes from original dancers for many years to come.

Marcelo de Andrade Pereira - I imagine this will take a lot of your work. What are the challenges of re-staging an early piece of Pina, like the Die sieben todsünden?

Josephine Ann Endicott - At this moment I am actually exhausted from this setting up of Todsünden. It has been a monstrous job. I would compare it to something like a small village which has been run down and my job was to rebuild it up fresh and new for new people to live in. I am not an architect but have the existing tools and stones and material necessary to do it. When we created this evening in 1976 I was there. I played the main role of Anna in Todsünden and had lots to do in second part of evening called Fürchtet euch nicht. One could say I was born with this piece. I know the piece as if it were mine as if it were my second skin. I don't see myself as a dancer but as someone who has been gifted to move - not only my body but the many feelings abiding and living in my person. My greatest quality as a dancer was to stay human and be myself on stage at all times, to live each performance - there and now. I know this. The last time I performed the role of Anna in Die sieben todsünden was in Berlin just 5 months after Pina had passed away. I was 59 years.

Now, in 2018 I shared the rehearsal director position with Julie Shanahan. I am happy with the end result and with the mixture of young, old and middle aged generation of dancers. It was more than wonderful to have been able to dance in it myself in the second half. All my shoes and dresses 
are 42 years old, original from the year of the creation in 1976. This for me was so very special. Performing again was amazing, like magic. The public were more than happy to have this exquisite evening brought back in to the repertoire again. Of course no-one can imagine how much work was involved to bring it to the necessary high quality and to give it the right spirit.

Marcelo de Andrade Pereira - Why did you do it?

Josephine Ann Endicott - Why did I say yes to Todsünden?! I must be crazy. I wanted to spread my knowledge, energy and courage to help inspire all the new dancers not only by working with me as rehearsal director but also by giving them the chance to experience and to be with me live and alive on stage, one last time in memory of Pina Bausch.

Rehearsal Director is the most difficult job anyone would want to have in the Tanztheater now. The responsibility is enormous. Let's hope the new Director Adolphe Binder will see her way thru the state of turmoil Pina left when she passed away.

\section{Reference}

KONTAKTHOF - with ladies and gentlemen over “65”. Paris: L'Arche, 2007.

This unpublished text is also published in Portuguese in this issue.

This is an open-access article distributed under the terms of the Creative Commons Attribution License 4.0 International. Available at: <http://creative commons.org/licenses/by/4.0>. 